\title{
PERMASALAHAN MATEMATIKA ARITMATIKA SOSIAL DALAM BENTUK CERITA: BAGAIMANA DESKRIPSI KESALAHAN-KESALAHAN JAWABAN SISWA?
}

\author{
Rini Nuraeni' ${ }^{1}$, Suny Guinesya Ardiansyah'2, Luvy Sylviana Zanthy ${ }^{3}$ \\ 1,2,3 IKIP Siliwangi Bandung, Jl. Terusan Jenderal Sudirman, Cimahi, Indonesia \\ Email: oriensayang84@gmail.com
}

\begin{abstract}
The story is one of the mathematical problems that often cause problems in doing so, so that math problems in the form of stories become difficult for most students. Social arithmetic is an important material that students learn because this material is related to the mathematical application in everyday life, such as sales and purchase prices, profit and loss, interest rates, discounts, taxes, and gross. The purpose of this research is to analyse the mistakes of students in working on social arithmetic material in the form of stories. This type of research is qualitative research using case study methods. The subject of this study was a grade VII student at one of the MTs in Cimahi. The collection of data in this study was done by observation methods, tests, and interviews. The data analyzed are from 10 students' answers from 31 students' answers using the stages of analysis techniques consisting of: data collection, data processing, data storage, and withdrawal of conclusions. Results obtained in this study that there are three types of mistakes students work on the problem, namely: (1) error in the concept; (2) the formulation of mathematical models; and (3) writing mathematical symbols. These mistakes are caused because students have not understood the social arithmetic material well.
\end{abstract}

Keyword: Social arithmetic, form of stories, analyze errors

\section{ABSTRAK}

Soal bentuk cerita merupakan salah satu persoalan matematika yang sering menimbulkan masalah-masalah dalam mengerjakannya, sehingga soal matematika dalam bentuk cerita menjadi dianggap sulit bagi kebanyakan siswa. Aritmatika sosial merupakan materi yang penting dipelajari siswa karena materi ini berhubungan dengan aplikasi matematika dalam kehidupan sehari-hari, seperti harga penjualan dan pembelian, untung dan rugi, suku bunga, diskon, pajak, dan bruto. Tujuan penelitian ini adalah untuk menganalisis kesalahan siswa dalam mengerjakan soal materi aritmatika sosial dalam bentuk cerita. Jenis penelitian ini adalah penelitian kualitatif dengan menggunakan metode studi kasus. Subjek penelitian ini adalah siswa kelas VII pada salah satu MTs yang berada di kota Cimahi. Pengumpulan data dalam penelitian ini dilakukan dengan metode observasi, tes, dan wawancara. Data yang dianalisis berasal dari 10 jawaban siswa dari 31 jawaban siswa dengan menggunakan tahapan teknik analisis yang terdiri atas: pengumpulan data, pengolahan data, peyajian data, dan penarikan kesimpulan. Hasil yang diperoleh dalam penelitian ini bahwa terdapat tiga jenis kesalahan siswa dalam mengerjakan soal, yaitu: (1) kesalahan dalam konsep; (2) penyusunan model matematika; dan (3) penulisan simbolsimbol matematika. Kesalahan-kesalahan ini disebabkan karena siswa belum memahami materi aritmatika sosial dengan baik.

Kata kunci: Aritmatika sosial, soal cerita, anasilis kesalahan

Dikirim: 12 Maret 2020; Diterima: 12 Maret 2020; Dipublikasikan: 30 Maret 2020

Cara sitasi: Nuraeni, R., Ardiansyah, S. G., \& Zanthy, L. S. (2020). Permasalahan matematika aritmatika sosial dalam bentuk cerita: bagaimana deskripsi kesalahan-kesalahan jawaban siswa? Teorema: Teori dan Riset Matematika, 5(1), 61-68. 


\section{PENDAHULUAN}

Matematika merupakan suatu ilmu pengetahuan yang kaitannya erat dengan aspek kehidupan sehari-hari serta berperan penting dalam perkembangan ilmu pengetahuan. Reys (Ruseffendi, 1990), menyatakan bahwa matematika adalah kajian tentang bentuk dan ikatan, suatu jalan atau cara berpikir, suatu seni dan suatu alat. Selain itu, menurut James \& James (Ruseffendi, 1990) di dalam kamus matematika bahwa matematika adalah ilmu logika yang berkenaan dengan pola, tahapan, pengukuran, dan konsep-konsep berkenaan lainnya yang totalnya banyak.

Matematika merupakan mata pelajaran yang masih dianggap sulit oleh sebagian siswa terlebih ketika dihadirkan soal matematika yang bentuknya soal cerita, padahal soal matematika dalam bentuk cerita berperan aktif dalam kehidupan sehari-hari, sebab soal tersebut mengedepankan permasalahan nyata yang sesuai dengan kehidupan sehari-hari. Dengan demikian, jika siswa bisa mengerjakan soal matematika dalam bentuk cerita maka secara otomatis siswa akan mampu menyelesaikan permasalahan tersebut di dalam kehidupan sehari-hari. Hal ini dilakukan agar siswa terlatih dan berpikir secara deduktif, dan juga dapat mengatasi keterampilan matematika serta mempererat penguasaan terhadap konsep matematika.

Tujuan pembelajaran matematika menurut Permendikbud (Zakiah et.al, 2019) agar para siswa memiliki kemampuan meliputi: (1) sikap logis, kritis, kreatif, cermat dan teliti, mempunyai rasa tanggung jawab, sikap responsif, serta tidak gampang menyerah dalam menyelesaikan suatu permasalahan; (2) rasa ingin tahu, kepercayaan diri, motivasi belajar terus menerus, berpikir reflektif dan mempunyai ketertarikan terhadap matematika; (3) rasa percaya terhadap manfaat mempelajari matematika, serta sikap kritis dari hasil pengalaman belajar yang dilakukannya; (4) sikap terbuka, objektif, dan penghargaan kepada hasil karya orang lain dari hasil interaksi secara kelompok ataupun aktivitas dalam kehidupan sehari-hari; dan (5) mampu mengkomunikasikan ide/gagasan matematika secara jelas dan efektif.

Matematika sangat dibutuhkan dalam kehidupan sehari-hari untuk memecahkan masalah serta mampu menyelesaikan masalah. Namun pada kenyataannya masih banyak yang terjadi kesalahan-kesalahan menyelesaikan soal matematika dalam bentuk cerita (Nurdiawan \& Zanthy, 2015). Hal tersebut berpengaruh terhadap prestasi belajar matematika siswa baik dalam ulangan harian maupun ulangan semester dengan hasil yang belum memuaskan, terlebih yang kaitannya dengan soal matematika dalam bentuk cerita.

Hasil dari pengerjaan siswa dapat digunakan untuk melihat kesalahan belajar siswa yang menjadi penyebab berlakunya kesalahan dalam mengerjakan soal. Evaluasi pembelajaran adalah serangkaian kegiatan untuk mencapai, menganalisis, serta menjelaskan data mengenai proses dan hasil belajar siswa yang dikerjakan secara teratur dan berkelanjutan sampai menjadi informasi yang berarti dalam mengambil keputusan (Setyono \& Sutarni, 2013).

Jika dilihat dari data hasil Ujian Nasional dari halaman website KEMDIKBUD terdapat beberapa mata pelajaran yang diujiankan dalam Ujian Nasional pada tahun 2019. Diperoleh hasil bahwa matematika menjadi nilai paling rendah dari mulai jenjang Sekolah Dasar hingga Sekolah Menengah. Selain itu, Husna et.al (2019) berpendapat bahwa penyebab siswa merasa kesulitan dalam mempelajari matematika karena siswa kurang memahami konsep dan teori yang telah dipelajari pada matematika itu sendiri. Maka dari itu perlu adanya penelitian guna meningkatkan hasil belajar peserta didik pada tiap jenjang pendidikan.

Aritmatika sosial adalah salah satu pokok bahasan yang dipelajari di tingkat SMP. Materi yang dipelajari meliputi harga penjualan, harga pembelian, keuntungan, kerugian, bunga, diskon, pajak, bruto, tara, dan neto. Pokok bahasan aritmatika sosial tersebut akan memberikan manfaat bagi siswa pada saat menyelesaikan permasalahan dalam kehidupan sehari-hari pada masa yang akan datang. Walaupun pentingnya materi tersebut untuk dipelajari, namun kebanyakan siswa masih mengalami kesulitan dalam menyelesaikan permasalahan yang berhubungan dengan materi aritmatika sosial, sehingga perlu dilakukan penelitian untuk menganalisis permasalahan tersebut. 
Penelitian yang telah dilakukan oleh Evijayanti \& Khotimah (2018) diperoleh hasil bahwa dalam menyelesaikan soal cerita aritmatika sosial teridentifikasi menjadi tiga macam kesulitan yang dilakukan siswa, yaitu: (1) memahami soal; (2) membuat pemodelan matematika; dan (3) proses penyelesaian. Faktor yang menyebabkan hal tersebut terjadi adalah siswa tidak secara seksama membaca soal teks yang panjang, motivasi belajar siswa yang kurang, siswa terbiasa menghafal rumus dibandingkan memahami konsep, siswa kurang mengerjakan latihan-latihan soal, masih melakukan kesalahan dalam proses perhitungan, proses pembelajaran di kelas kurang kondusif dan penggunaan metode pembelajaran yang belum bervariasi. Sejalan dengan penelitian tersebut, penelitian lain mengungkapkan bahwa kesulitan-kesulitan siswa dalam menyelesaikan soal aritmatika sosial diantaranya dalam memahami konsep yang saling berkaitan dan melakukan algoritma penyelesaian soal (Shalikhah, 2019).

Proses pembelajaran yang menghubungkan antara materi pelajaran dengan konteks kehidupan sehari-hari dapat membiasakan siswa untuk melakukan proses perencanaan strategi penyelesaian masalah, melakukan penyelesaian masalah, melakukan pemantauan terhadap proses penyelesaian masalah, dan melakukan evaluasi terhadap hasil pekerjaan yang sudah diperolehnya (Zakiah et.al, 2019). Pendapat senada diungkapkan oleh Aqib (2013) bahwa pendekatan kontekstual merupakan salah satu alternatif untuk meningkatkan kemampuan siswa dalam pencapaian hasil belajar kompetensi-kompetensi, juga bisa digunakan untuk membantu kesulitan belajar yang dialami oleh siswa. Kontekstual dapat diterapkan ke semua kurikulum dan bidang studi apa saja serta berbagai keadaan kelas. Selain itu, menurut Silver bahwa pembelajaran dengan menghubungkan antara materi pembelajaran dengan konteks kehidupan sehari-hari akan memberikan pengalaman yang banyak dalam menafsirkan masalah dan akan mampu menumbuhkan ide/gagasan bervariasi dalam menyelesaikan masalah (Zakiah et.al, 2019).

Berdasarkan latar belakang masalah tersebut, maka peneliti tertarik untuk melakukan identifikasi berkenaan dengan kelasalahan siswa SMP kelas VII dalam menyelesaikan soal matematika dalam bentuk cerita pada materi aritmatika sosial. Identifikasi kesalahan tersebut mencakup analisis untuk menghitung tingkat kesalahan dan analisis untuk menyaksikan kesulitan belajar siswa apa penyebab terjadinya siswa melakukan kesalahan dalam mengerjakan soal matematika dalam bentuk cerita pada materi Aritmatika Sosial. Semoga hasil penelitian ini dapat bermanfaat untuk guru, calon guru, siswa, dan lembaga-lembaga pendidikan guna peningkatan mutu kualitas pendidikan matematika.

\section{METODE PENELITIAN}

Jenis penelitian yang digunakan yakni penelitian yang bersifat kualitatif dengan metode studi kasus. Dimana peneliti berusaha menganalisis kesalahan-kesalahan dalam mengerjakan soal matematika dalam bentuk cerita pada materi aritmatika sosial. Penelitian kualitatif dibarengi dengan pemilihan sampel secara purposive sampling. Penelitian kualitatif dalam penelitian ini dilakukan untuk mengkaji sampel kecil dari individu-individu yang sengaja dipilih. Peneliti mengambil subjek pada penelitian ini adalah siswa kelas VII di salah satu MTs yang berada di Kota Cimahi yang mengalami kesulitan dalam mengerjakan soal dalam bentuk cerita pada materi aritmatika soal, yaitu memilih 10 jawaban dari 31 jawaban siswa.

Pengumpulan data dalam penelitian ini dilakukan dengan metode observasi, tes, dan wawancara. Sebelum dilaksanakan wawancara terlebih dahulu siswa diberikan tes soal aritmatika sosial dalam bentuk soal cerita. Selanjutnya, teknik analisis yang digunakan dalam penelitian ini adalah model analisis kualitatif yang mengacu pada konsep yang diberikan oleh Miles \& Huberman (Sari, 2017) yang terdiri atas: pengumpulan data, pengolahan data, peyajian data, dan penarikan kesimpulan. 


\section{HASIL DAN PEMBAHASAN}

Pada saat siswa menerima soal matematika, mereka dapat mengerjakan hingga selesai. Walaupun siswa merasa kesulitan dalam menjawab soal. Pada saat membaca soal, kesulitan siswa yaitu merubah dari soal cerita ke bentuk pemodelan matematika, siswa kesulitan dalam penulisan simbol-simbol sehingga beberapa siswa tidak menuliskan apa yang diketahuinya dengan simbol melainkan siswa menuliskan kembali tulisan yang diketahui pada soal. Pada analisis kesalahan membuat pemodelan matematikan siswa juga tidak memperhatikan permasalahan dalam soal tersebut, mereka tidak cermat dalam membaca pertanyaan apa yang dimaksud dalam soal, sehingga kebanyakan jawaban siswa hanya sampai mencari keuntungan atau kerugian tanpa merubah ke dalam bentuk persentase salah satunya. Tentu itu menjadi masalah besar bagi siswa.

Masalah selanjutnya timbul ketika siswa menjawab hasil keuntungan dari $20 \mathrm{~kg}$ penjualan suatu produk yaitu ketika siswa tidak dengan jelas menuliskan proses pengerjaannya. Padahal hasil akhir dari siswa sudah betul. Tentu ini menjadi suatu masalah bagi siswa karena tidak bisa menyajikan apa yang mereka pikirkan ke dalam tulisan sehingga timbul permasalahan dari penyusunan model matematika. Kesalahan yang terjadi selanjutnya yaitu mengenai permasalahan pada konsep yang harusnya diketahui oleh siswa. Tidak semua siswa mengetahui arti kata dari Bruto, Neto, dan Tara sehingga mereka keliru dalam pengerjaan soal.

Berikut ini peneliti sajikan sebuah tabel yang menggambarkan kondisi 31 jawaban siswa yang mengalami kesulitan dalam menyelesaikan soal matematika dalam bentuk cerita.

\section{Tabel 1.}

Rangkuman hasil jawaban siswa soal aritmatika sosial

\begin{tabular}{ccccc}
\hline Soal & $\begin{array}{c}\text { Siswa yang menjawab } \\
\text { salah }\end{array}$ & $\begin{array}{c}\text { Persentase siswa } \\
\text { yang menjawab salah }\end{array}$ & $\begin{array}{c}\text { Siswa yang } \\
\text { menjawab benar }\end{array}$ & $\begin{array}{c}\text { Persentase siswa } \\
\text { yang menjawab } \\
\text { benar }\end{array}$ \\
\hline 1 & 7 & $70 \%$ & 3 & $30 \%$ \\
2 & 9 & $90 \%$ & 1 & $10 \%$ \\
3 & 4 & $40 \%$ & 6 & $60 \%$ \\
\hline
\end{tabular}

Hasil persentase tersebut di atas diambil dari 3 soal yang diujikan pada indikator soal yang diambil dari kompetensi dasar materi aritmatika sosial.

Permasalahan nomor 1 :

Bu Aisyah membeli dua karung beras dari sebuah grosir. Setelah ditimbang, diketahui bahwa berat kotor (bruto) dari masing-masing karung beras adalah $51 \mathrm{~kg}$ dan berat bersihnya (neto) yaitu $50 \mathrm{~kg}$. Berdasarkan keterangan tersebut, nyatakanlah antara bruto, neto, dan tara dengan bahasamu sendiri. Kemudian hitunglah bruto, neto, dan tara dari dua karung tersebut.

Jawaban siswa:
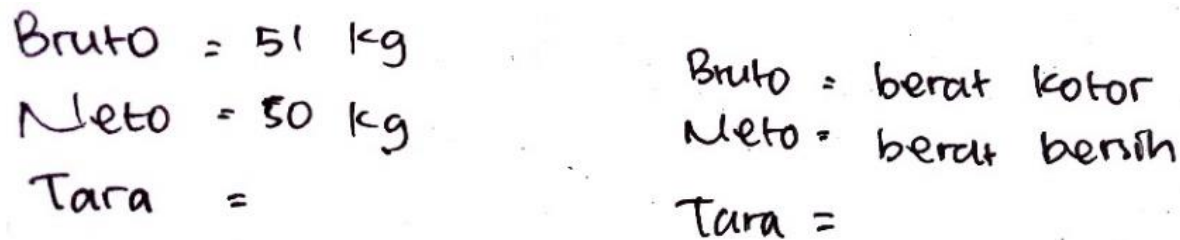

\section{Gambar 1. Jawaban siswa pada soal nomor 1}

Dari jawaban pada Gambar 1 dapat dilihat bahwa kesalahan siswa tersebut adalah siswa tidak mengetahui maksud dari kata bruto, neto, dan tara. Siswa hanya menyalin jawaban dari soal yang ada dan ketika menuju ke tara karena tidak ada keterangannya siswa tidak menjawabnya. Sehingga dapat disimpulkan kesalahan tersebut terjadi dari pemahaman siswa dalam materi aritmatika sosial, yang bisa disebut kesalahan konsep. Kesalahan konsep ini bisa berpengaruh pada tahap lainnya. Ketika siswa tidak tahu konsep apa yang harus digunakan, siswa tidak akan bisa menjawab persoalan yang ada. 
Untuk mengetahui alasan siswa subjek 1 dalam menjawab soal yang diberikan, kemudian peneliti melakukan wawancara yang disajikan berikut.

Peneliti : Coba lihat soal nomor 1. Soal nomor 1 itu tentang apa?

Subjek 1 : Tentang bruto, neto, dan tara bu

Peneliti : Apa itu bruto, neto, dan tara?

Subjek 1 : Tidak tau bu

Peneliti : Apa alasan kamu menjawab seperti yang tertulis pada kertas ini?

Subjek 1 : Saya menjawab mengikuti soal saja bu apa yang ada di soal saya tulis

Peneliti : Apa kamu ingat materi aritmatika sosial?

Subjek 1 : Lupa lagi bu

Berdasarkan hasil wawancara tersebut maka dapat disimpulkan bahwa siswa subjek 1 tidak mengetahui materi soal yang sedang dikerjakan. Hal tersebut menunjukkan ciri-ciri bahwa subjek mengalami kesulitan dalam memahami konsep. Siswa hanya menebak jawaban dari soal tersebut. Kesalahan selanjutnya dapat dilihat pada soal berikut.

Permasalahan nomor 2:

Pak H. Abdul Hamid membelikan mobil mainan aki untuk anaknya dengan harga Rp. 1.500.000,- dari sebuah toko. 3 bulan setelah itu, Pak H. Abdul Hamid memutuskan untuk menjual mobil mainan aki tersebut. Karena Pak H. Abdul Hamid tidak ingin mengalami kerugian yang besar, maka mobil tersebut dijual dengan harga harga 1.350.000. berapa persenkah kerugian yang dialami Pak H. Abdul Hamid? Jawaban siswa:

$$
\begin{aligned}
& \text { 2. Pak Abdul membeli mobil Rp. } 1.500 .000 \\
& \text { Pak Abdul menjual mbl Rp. } 1.350 .000 \\
& \frac{\text { Rp. } 150.000}{-}
\end{aligned}
$$

\section{Gambar 2. Jawaban siswa pada soal nomor 2}

Pada jawaban yang tercantum di Gambar 2, kesulitan yang dialami siswa terjadi dalam penulisan simbol karena ketidaktahuan siswa pada simbol apa yang digunakan dalam jawaban, siswa memilih untuk tidak menggunakan simbol. Siswa menuliskan sesuai apa yang diketahuinya dari hasil soal yang dibaca. Selanjutnya adalah kesalahan terjadi pada hasil akhir. Kerugian yang dialami memang sebesar Rp. 150.000. Akan tetapi, pertanyaan dari soal tersebut adalah berupa persentase. Tentu ini terjadi karena ketidaktelitian siswa dalam menjawab soal. Ini menjadi kesalahan besar karena hasil yang dicari tidak sesuai dengan maksud dari soal yang diberikan.

Selanjutnya, penulis melakukan wawancara dengan siswa subjek 2 untuk mengetahui alasan subjek penelitian memberi jawaban seperti yang tertera pada Gambar 2. Hasil wawancara disajikan berikut.

Peneliti : Coba lihat soal nomor 2.

Subjek 2 : Iya bu bagaimana?

Peneliti : Apa perintah dari soal tersebut?

Subjek 2 : Kita disuruh mencari persentase dari kerugian yang dialami Pak Hamid.

Peneliti : Bagaimana cara mencari penyelesaiannya?

Subjek 2 : Saya lupa bu.

Berdasarkan hasil wawancara dengan siswa subjek 2 sangat jelas terlihat bahwa siswa tersebut belum memahami apa yang menjadi perintah dalam soal tersebut. Selain itu, siswa juga belum mengetahui metode-metode yang digunakan dalam menyelesaikan masalah. 
Permasalahan nomor 3:

Pak Wahyu membeli banyak dodol dengan harga Rp. 25.000/kg. la kemudian menjual kembali dodol yang dibelinya dengan harga Rp. 30.000/kg. Jika Pak Wahyu berhasil menjual dodolnya sebanyak $20 \mathrm{~kg}$. Berapakah keuntungan yang diperoleh Pak Wahyu?

Jawaban siswa:

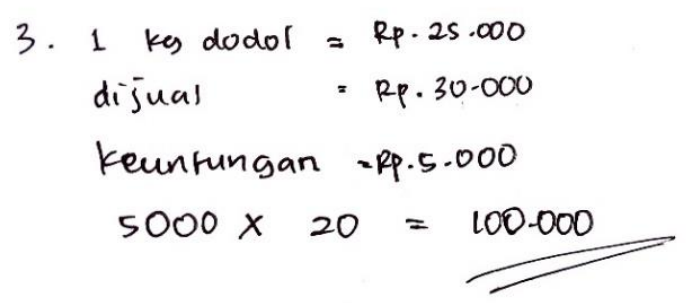

\section{Gambar 3. Jawaban siswa pada soal nomor 3}

Pada jawaban tersebut, siswa berhasil mendapatkan hasil keuntungan yakni Rp. 100.000. Tetapi, jika dilihat dari proses mendapatkan jawabannya tersebut terdapat kesalahan, yaitu kesalahan dalam pemodelan dan keterangan. Siswa kurang jelas dalam menuliskan hasil yang diperoleh dalam soal, walaupun hasilnya betul. Dalam jawabannya yg terakhir siswa tidak menuliskan keterangan yang menyatakan hasil dari $20 \mathrm{~kg}$ dan tidak juga menuliskan hasil keuntungan yang diperoleh Rp. 100.000. Karena soal dalam bentuk cerita seharusnya siswa bisa lebih jelas dalam menuliskan jawaban beserta keterangannya agar siswa tersebut bisa langsung memahami untuk pengerjaan selanjutnya.

Untuk mengetahui alasan subjek memberikan jawaban pada soal tersebut, peneliti melakukan wawancara dengan siswa subjek 3 tersebut.

Peneliti : Coba lihat soal nomor 3.

Subjek 3 : lya bu.

Peneliti : Apa perintah dari soal tersebut?

Subjek 3 : Kita disuruh mencari tahu keuntungan dari penjualan dodol.

Peneliti : Bagaimana cara menyelesaikannya?

Subjek 3 : lya begitu bu sesuai dengan jawaban.

Peneliti : Coba lihat mana yang menjadi keuntungan?

Subjek 3 : yang ini bu yang 100.000

Peneliti : Sudah betul, seharusnya ada keterangan atau ada kesimpulan "Jadi keuntungan yang dihasilkan adalah Rp. 100.000"

Subjek 3 : Oh iya bu.

Dari pernyataan tersebut kesalahan siswa terletak pada keterangan hasil jawaban siswa yang kurang jelas karena tidak adanya kata-kata pendukung dalam penentuan jawaban. Siswa langsung menuliskan jawabannya yaitu 100.000 tanpa menuliskan kata keterangan keuntungan.

Pada pembahasan yang telah diuraikan dapat dilihat masalah-masalah yang timbul adalah kurangnya pemahaman siswa pada materi tersebut serta masih rendahnya kemampuan berpikir siswa pada proses penyederhanaan atau pemisalan menggunakan variabel yang akan memudahkan dalam proses pengerjaan. Selanjutnya keterangan-keterangan untuk menjawab pertanyaan pada soal yang harusnya nampak pada setiap jawaban tidak ada sehingga ketika dilihat oleh orang lain pada jawabannya akan kebingungan. Kesalahan-kesalahan tersebut yang harus diperbaiki supaya tidak berkelanjutan ke jenjang berikutnya.

Berdasarkan hasil penelitian tersebut maka dapat ditemukan bahwa siswa dengan kesulitan konsep dan kesulitan verbal dalam menyelesaikan masalah yang berkaitan dengan aritmatika sosial baik itu dari kesulitan konsep, penyusunan dalam model matematika, dan kesalahan dalam penulisan simbol-simbol matematika. Dengan demikian maka faktor yang menjadi penyebab terjadinya kesulitan konsep, penyusunan model matematika, dan kesalahan penulisan simbol-simbol dalam matematika adalah masih rendahnya pemahaman siswa pada materi aritmatika sosial. 


\section{KESIMPULAN}

Berdasarkan penelitian yang telah dilakukan pada siswa kelas VII di salah satu MTs yang berada di Kota Cimahi diperoleh hasil bahwa dalam menyelesaikan soal matematika bentuk cerita pada materi aritmatika sosial, dapat disimpulkan bahwa kesalahan-kesalahan yang dilakukan oleh siswa dalam menjawab soal tersebut, yakni: (1) kesalahan dalam pembuatan model matematika; (2) kesalahan dalam konsep dan pengerjaan; dan (3) kesalahan dalam penulisan simbol dan keterangan. Dari data yang diolah, hampir seluruh siswa kurang memahami dengan soal matematika yang berbentuk cerita.

\section{REKOMENDASI}

Berdasarkan hasil penelitian, untuk meningkatkan pemahaman siswa di bidang matematika khusunya pada materi aritmatika sosial, perlu adanya tindakan di luar penelitian seperti guru memberikan teori tentang apa itu aritmatika sosial beserta pengertian dari tiap-tiap istilah yang ada. Untuk pembiasaan siswa juga dalam mengisi soal matematika, guru memberikan latihan-latihan soal kepada siswa beserta cara menjawab soal yang jelas dan benar dengan menggunakan istilah-istilah yang ada pada matematika pada umumnya. Selain itu, guru dapat menggunakan pendekatan atau teknik pembelajaran yang menarik sehingga menjadikan siswa senang belajar matematika yang akan menimbulkan penerapan konsep secara berkala. Untuk penelitian lanjutan, memungkinkan adanya penelitian lebih dalam lagi mengenai faktor apa saja yang membuat siswa kesulitan mengerjakan soal matematika bentuk cerita dan bagaimana cara mengatasi permasalahan tersebut.

\section{UCAPAN TERIMA KASIH}

Ucapan terima kasih yang sebesar-besarnya kepada Allah SWT, karena berkah dan karunianya yang sangat luar biasa sehingga kami dapat menyelesaikan artikel ini. Tak lupa terimakasih juga kepada kedua orang tua dan pihak-pihak yang telah memberikan dukungan yang sangat membantu pada proses penyelesaian artikel ini. Semoga artikel yang kami buat ini dapat bermanfaat terhadap pembaca pada umumnya.

\section{DAFTAR PUSTAKA}

Aqib, Z. (2013). Model-model, media, dan strategi pembelajaran kontekstual (inovatif). Bandung: Yrama Widya.

Evijayanti, W., \& Khotimah, R. P. (2018). Analisis kesulitan siswa smp dalam menyelesaikan soal cerita aritmatika sosial. Prosiding Seminar Nasional Matematika dan Pendidikan Matematika (Sesiomadika), 295-302.

Nurdiawan, R., \& Zanthy, L. S. (2015). Analisis Kesalahan dalam Menyelesaikan Soal Cerita Pada Materi Himpunan Berdasarkan Tahapan Newman. Journal on Education. 01(03), 128-134.

Pusat Penilaian Pendidikan. (2019). Laporan hasil ujian nasional. http://hasilun.puspendik.kemdikbud.go.ig/\#2019!smp!capaian_nasional!99\&99\&999!T\&T\&T\& T\&1\&!1!\&. (diakses pada 5 Maret 2020)

Ruseffendi, E. (1990). Pengajaran matematika modern dan masa kini. Bandung: Tarsito.

Sari, A. W. (2017). Diagnosis kesulitan belajar matematika siswa di tinjau dari kemampuan koneksi matematika siswa kelas viii smp muhammadiyah 2 kartasura tahun pelajaran 2016/2017. Chemosphere, 7(1), 13-19. 
Shalikhah, M. (2019). Analisis kesulitan siswa smp negeri 3 pleret pada hmateri aritmatika sosial. Academy of Education Journal, 10(1), 44-54.

Setyono, D \& Sutarni, S. (2013). Kesalahan menyelesaikan soal matematika dalam bentuk soal cerita pokok bahasan aritmatika sosial. Makalah disajikan dalam Seminar Nasional Pendidikan Matematika, FKIP UMS, 15 Mei 2019.

Zakiah, N. E., Sunaryo, Y., \& Amam, A. (2019). Implementasi pendekatan kontekstual pada model pembelajaran berbasis masalah berdasarkan langkah-langkah polya. Teorema: Teori dan Riset Matematika, 4(2), 111-120. 